\title{
INVERTING IMAGE AND REALITY: R. v. Sharpe AND the Moral Panic AROUND CHILD PORNOGRAPHY
}

\author{
Lise Gotell
}

Banalizing the awful and numbing the conscience, exposure to child pornoraphy may make the abnormal seem normal and the immoral seem acceptable. ${ }^{1}$

In the atmosphere of high anxiety surrounding the Supreme Court's decision in $R$. v. Sharpe, abnormal and normal collide and fantasy and representation become equated with reality. It is my intent in this short article to explore the complex cultural and political conditions that give meaning to the Supreme Court's unanimous endorsement of stiff criminal penalties for possessing sexual representations of adolescents and children. In the Criminal Code provisions on child pornography and in the discursive web woven by both the majority and minority opinions in Sharpe, anxieties about the well-being of children are being projected onto the highly symbolic target of child pornography. Any dissent is pathologized and cast into what has become an elastic category - "the pedophile." As Weeks writes, "[m]oral panic occurs in complex societies when deep rooted and difficult to resolve social anxieties become focussed on symbolic agents that can be easily targeted."2 There is strong evidence that we are in the midst of a moral panic around child pornography, the contours of which require careful analysis.

\footnotetext{
R. v. Sharpe, [2001] S.J.C. No. 3 at para. 88 per McLachlin C.J.C. [hereinafter Sharpe].

J. Weeks, Against Nature (London: River Ocam Press, 1991) at 118 [hereinafter Against Nature].
}

\section{The Criminal Code Provisions}

Bill C-128, creating a number of specific criminal offences relating to child pornography, ${ }^{3}$ was rushed through Parliament in the dying days of the Mulroney government. The stated intent of the new child pornography law was to "deal with the sexual abuse and exploitation of children." ${ }^{4}$ Concerns about the use of children in the production of sexually explicit images had been raised in the mid-1980s in the Badgley Report and in the Fraser Report. ${ }^{5}$ Both reports had recommended the creation of an offence limited to

Criminal Code, R.S.C. 1985 , c. C-46, s. 163.1 as added by S.C. 1993 , c. 46 , s. 2.

163.1 (1) In this section, "child pornography" means

(a) A photographic, film, video or other visual representation, whether or not it was made by electronic or mechanical means,

(i) that shows a person who is or is depicted as being under the age of eighteen years and is engaged in or is depicted as engaged in explicit sexual activity, or

(ii) the dominant characteristic of which is the depiction, for a sexual purpose, of a sexual organ or the anal region of a person under the age of eighteen years; or

(b) any written material or visual representation that advocates or counsels sexual activity with a person under the age of eighteen years that would be an offence under this Act.

(4) Every person who possesses any child pornography is guilty of

(a) an indictable offence and liable to imprisonment for a term not exceeding five years; or

(b) an offence punishable on summary conviction.

Canada, House of Commons, Proceedings of the Standing Senate Committee on Justice and Legal Affairs, (3 June 1993) at 20328 .

5 Canada, Report of the Committee on Sexual Offences Against Children and Youths (Ottawa: Government of Canada, 1985) at 101-102 (Chair: Robin F. Badgley) [hereinafter Badgley Report]; Canada, Report of the Special Committee on Pornography and Prostitution (Ottawa: Minister of Supply and Services Canada, 1985) at 561-650 (Chair: Paul Fraser) [hereinafter Fraser Report]. 
visual depictions of real children, with Badgley committee members deeply divided on the issue of whether simple possession merited criminalization. ${ }^{6} \mathrm{At}$ first glance, the introduction of Bill C-128 appears to be a direct response to these reports, set also against an international climate in which many other national governments were passing legislation to combat the sexual abuse of children in pornography. ${ }^{7}$ In 1991, Canada ratified the United Nations Convention on the Rights of the Child, which required measures to prevent the exploitative use of children in pornographic materials. $^{8}$ International commitments and new concerns about Internet and computer pornography prompted a flurry of national legislative initiatives around child pornography in the 1980s and 1990s.

Canada's initiatives, however, were both stronger and more comprehensive. Bill $\mathrm{C}-128$ proliferated the criminal sanctions that had already been attached to child pornography. Sexual offense provisions in the Criminal Code prevent an accused from relying on the defense of consent of children under the age of fourteen. ${ }^{10}$ To record sexual activity with someone under fourteen is thus to depict what is already a criminal act. In upholding the obscenity provisions of the Criminal Code in $R$. v. Butler, Sopinka J. had specifically identified sexual representations that use children in their production as inherently harmful, constituting by definition the "undue exploitation of sex" and therefore criminally obscene. ${ }^{11}$ As Cossman and Bell emphasize, under the law as it existed prior to Bill $\mathrm{C}-128$, the production, distribution and sale of sexually explicit materials involving children was already prohibited, as was possession for the purposes of distribution and sale. ${ }^{12}$

Badgley Report, ibid. at 101-102; Fraser Report, ibid. at 584-85, 629 .

M. Healey, "Child Pornography: An International Perspective" working document for the World Congress on Sexual Exploitation of Children (2000) 1 at $15-22$, online: The Sex Positive Initiative <wysiwyg://11/http://www sexpositive.com/ SP.../production_essays/child_porn_congress.htm $>$ (date accessed: 31 July 2001).

8 Sharpe, supra note 1 at para. 171 per L'Heureux-Dubé J. Article 34 of the UN Convention on the Rights of the Child reads, "States Parties undertake to protect the child from all forms of sexual exploitation and sexual abuse. For these purposes, States Parties shall in particular take all appropriate national, bilateral and multilateral measure to prevent: ... c) The exploitative use of children in pornographic performances and materials." GA Res. 44/25, annex, UN GAOR, Supp. (No. 49) at 167, Agenda Item 44, UN Doc. A/44/49 (1989).

Healey, supra note 7 at 15-17.

10 Criminal Code, R.S.C. 1985, c. C-46, as added by S.C. 1993 , c. 19 ( $3^{\text {d }}$ Supp.), s. 1, s. 150.1 .

11 R. v. Butler, [1992] 1 S.C.R. 452 at para. 60 [hereinafter Butler].

12 B. Cossman \& S. Bell, "Introduction" in B. Cossman et al., eds., Bad Attitude/s on Trial (Toronto: University of Toronto, 1997) 3 at 39 .
Had the Mulroney government wanted to add a possession offence to the existing prohibitions, it could have done so with a minor amendment to the Criminal Code. To take such a path, however, would have been to miss out on the high symbolism of creating a new child pornography law. Bill C-128 stood as an emphatic expression of governmental concern over the sexual exploitation of children. In departure from the existing obscenity regime, offering no statutory definition of "obscene" beyond the vague phrase, "undue exploitation of sex," the new section 163.1 of the Criminal Code codified a detailed and expansive definition of "child pornography." The legislation adopted a literalist approach to defining child pornography. ${ }^{13}$ Implicit in such an approach is the assumption that representations contain unambiguous meanings and thus there can be a clearly demarcated category of "child pornography." It is assumed that one can easily determine whether or not any representation falls within this category by a simple exercise in observation independent of context.

According to the definition set out in section 163.1, child pornography is, first of all, any visual representation of a child engaged in sexual activity or depiction "for a sexual purpose" of the genital or anal region of a child. ${ }^{14}$ This first element is entirely consistent with the kind of material targeted in the recommendations of the Badgely Report ${ }^{15}$ and the Fraser Report ${ }^{16}$ and in international documents like the United Nations Convention. ${ }^{17}$ But section 163.1 exceeds this definition in several significant ways. Included within the enlarged criminally prohibited category of child pornography are written materials that "advocate or counsel sexual activity with a child" 18 and sexual representations in which an adult pretends to be a child. ${ }^{19}$ In these respects, Bill C-128 criminalizes materials that are pure fantasy and involve no real children in their production. ${ }^{20}$ And remarkably, section 163.1 defines a child as anyone under the age of eighteen, even though under age of consent provisions adolescents fourteen to seventeen years old can legally

13 See B. Arcand, The Jaguar and the Anteater: Pornography and the Modern World (Toronto: McLelland \& Stewart, 1991) at 24-25 for a discussion of this approach.

Supra note 3, ss. 163.1(a)(i) and (ii).

Badgley Report, supra note 5.

Fraser Report, supra note 5.

Supra note 8 .

Supra note 3, s. 163.1(b).

Ibid., s. 163.1(a)(i).

Cossman \& Bell, supra note 12 at 39; K. Doyle \& D. Lacombe, "Scapegoat in Risk Society: The Case of the Pedophile/Child Pornographer Robin Sharpe" (2000) 20 Stud. Law Polit. Soc. 184 at 194. 
engage in sexual activity. ${ }^{21}$ The new provisions also attach stiff penalties to child pornography, making it an offense punishable by up to ten years imprisonment to make, distribute or possess for the purposes of distribution and creating an offence of simple possession, punishable by up to five years imprisonment. $^{22}$

Many other legislative schemes passed in the last fifteen years do criminalize possession, based upon the rationale that this will both reduce the market for images whose production involves sexual exploitation and remove the often difficult task of proving intent to distribute. ${ }^{23}$ Canada's law is by no means unique in this respect. Yet in combining a possession offence with an extremely broad definition of child pornography and in the level of penalties established, the Canadian legislation constitutes what is widely recognized as one of the strongest criminal laws in the world.$^{24}$ In fact, as Doyle and Lacombe contend, this is a "[d]raconian law that could only have come out of a climate of panic." 25 Elements of this panic lurk just beneath what appears to be a concerned legislative response to child sexual abuse. If the story of Canada's child pornography law tells us anything, it is that first glances can be deceptive.

\section{THE LAW AND ORDER STATE}

The introduction of Bill $\mathrm{C}-128$ stands as an expression of the kind of state that is emerging from the ashes of the old Keynesian state. Like a Phoenix, the neoliberal state is born both lithe and strong. The hyperpoliticization of child pornography that began with the enactment of Bill C-128, and has continued on in governmental hysteria around the Sharpe case, must be understood within the broader context of the elaboration of a new state form. The neoliberal state seeks legitimation through its ability to constrain itself: to retreat from the economy; to reduce social spending; and to eliminate budgetary deficits. At the same time as this state represents a "rolling back" however, it simultaneously has meant a rolling forward. As the components of the post-war order are dismantled, including the welfare state, the need for strong government to maintain social order correspondingly increases. As Keane writes, neoliberalism works "to

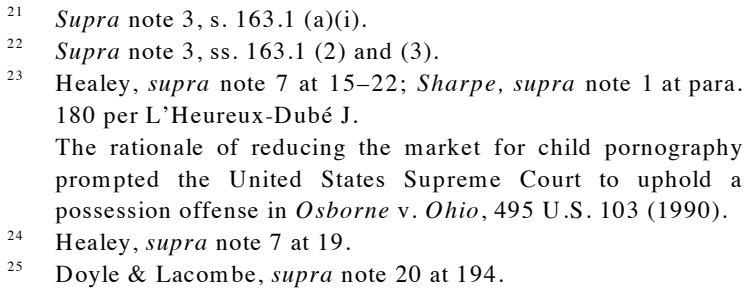

increase the effectiveness of state policies by downgrading the instrumental dimensions of the state (as provider of goods and services to civil society) in favour of its role as a powerful, prestigious and enduring guardian of the Nation ... as a guarantor of domestic law and order [and] social stability." 26

As I have argued elsewhere, from the election of the Tories in 1984, through Liberal governments of the 1990 s, criminalization became an increasingly preferred response to social anxieties. It was preferred because it promises to contain social disorder, preferred because it enhances the authority of the state, preferred because it can promise to accomplish these things without, at the same time, departing from the neoliberal objective of reducing social spending. ${ }^{27}$ Criminalization is politically attractive because it simplifies conflicts, stresses moral outrage over reason, allocates blame, and offers concrete goals. Over the past fifteen years, for example, governmental efforts to appear responsive to women's issues have been framed almost entirely within a law and order agenda. The complexities of gender subordination have been swallowed into "violence against women." As this discursive narrowing has occurred, new criminal justice initiatives proliferate and supplant broader equality enhancing, social policy responses. ${ }^{28}$

At this point, it may appear that I have wandered far from the topic of child pornography. But it is crucial, I think, to look at the figure of the "child" and the social importance of "child protection" from within this broad landscape. The child, of course, falls outside the rugged demands of neoliberal citizenship. ${ }^{29}$ One cannot hold a child responsible for his/her poverty; children cannot be subjected to workfare, for example. The problems of children can be attributed to individually blameworthy adults, with the symbolic figures of the "deadbeat dad" and the "welfare mother" rising to the status of neoliberal cultural icons in recent years. ${ }^{30}$ But, nevertheless, even as Canadian governments are busily shedding the obligations of

26 J. Keane, Democracy and Civil Society (London: Verso, 1988) at 8 .

27 L. Gotell, "A Critical Look at State Discourse on Violence Against Women: Some Implications for Feminist Politics and Women's Citizenship" in C. Andrew \& M. Tremblay, eds., Women and Political Representation in Canada (Ottawa: University of Ottawa Press, 1998) 39 [hereinafter "A Critical Look"]; L. Gotell, "Policing Desire: Obscenity Law, Pornography Policy and Feminism" in J. Brodie, ed., Women and Canadian Public Policy (Toronto: Harcourt Brace, 1996) 279.

28 "A Critical Look," ibid.

29 J. Brodie, "Meso-Discourses, State Forms and the Gendering of Liberal Democratic Citizenship" (1997) 1:2 Citizenship Studies 237.

$30 \quad$ Ibid. at 238 . 
social citizenship, they cannot abandon children in need. The Mulroney government's 1989 promise to end child poverty by the year $2000^{31}$ must be seen against this backdrop. Children, represented as if free floating from parents and communities, have been increasingly centred as objects of public policy.

But what kinds of public policies? Over the 1990s, the goal of deficit reduction, the erosion of universal social programs and deep cuts in transfer payments to the provinces have drastically weakened the social safety net. ${ }^{32}$ As neoliberalism reframes the role of the state, Canadian children, according to social activists, are substantially worse off at the beginning of the new millennium. ${ }^{33}$ The rate of child poverty increased by forty-three per cent over the $1990 \mathrm{~s}$, standing at nineteen per cent by $1998 .^{34}$ It is estimated that 256,406 Canadian children rely on food banks. ${ }^{35}$ There are good reasons to be concerned and perhaps even panicked about child welfare. But anxieties about the well-being of children have been contained and discursively redirected onto narrow and highly specific targets in recent years. The objective of "protecting" children has been framed within the law and order state and its preferred policy instrument of criminalization. A concerted governmental effort to enhance criminal penalties against child abuse has coincided with the attenuation of social policy responses to child welfare. Since 1988, thirteen law reform efforts have been initiated as a result of calls to protect children covering: sexual assault, sexual interference, invitation to sexual touching, sexual exploitation, indecent acts, incest, anal intercourse, guardians procuring sexual activity, householders permitting sexual activity, living off the avails of a prostitute under eighteen, obtaining a person

31 On 24 November 1989, the Mulroney Tories supported an allparty House of Commons resolution which stated "This house seeks to achieve the goal of eliminating poverty among Canadian children by the year 2000." Campaign 2000, End Child Poverty in Canada (2000), online: Campaign 2000 <http://www.campaign2000.ca/> (date accessed: 31 July 2001).

32 The federal government, with the demise of the Canada Assistance Plan in 1995, cut federal transfers to the provinces by an estimated $\$ 12$ billion. While substantial funding was restored to health care in 1999 , there were no similar increases for social welfare. Campaign 2000, Report Card on Child Poverty in Canada (2000) at 5-6, online: Campaign 2000 <http://www.campaign2000.ca/national_2.htm> (date accessed: 31 January 2001).

33 Campaign 2000, Child Poverty in Canada: A Report Card (2000) at 2, online: Campaign $2000<$ http://www. campaign $2000 . \mathrm{ca} /$ nat $\% 20 \mathrm{rc} \% 20 \mathrm{eng} \% 202000$.pdf $2 . \mathrm{htm}>$ (date accessed: 31 July 2001) [copy on file with author]; YWCA, "Press Release on Throne Speech" (30 January 2001), online: Policy Action Research List <PAR-L@ unb.ca> (date accessed: 31 January 2001) [copy on file with author].

34 Campaign 2000, ibid. at 2, 5 .

35 Forty per cent of food bank users are children, although children represent only twenty-six per cent of the Canadian population (ibid. at 12). under eighteen for a sexual purpose and crucially, child pornography. ${ }^{36}$ In the narrative underpinning such initiatives, Canadian children are constructed as being in danger and under threat from "criminals." "Criminals" become the evil outsiders of an unsettled variegated society, and we are invited to define ourselves against these dangerous "others." Child molesters, as Doyle and Lacombe contend, become "a sort of meta-criminal, the worst among various evils." 37 Simultaneously, society and governments are let off the hook. Criminalization works to individualize the attribution of responsibility for child welfare. Through the high symbolism of criminal law reforms like Bill $\mathrm{C}-128$, the state is positioned as the protector of innocent child victims.

\section{SeXuAl ANXIETIES, MORAL PANICS AND SCAPEGOATS}

Locating the intensified criminalization of child pornography within the law and order state provides us with one set of coordinates. The political and economic contours of the law and order state have a parallel in the realm of the sexual. Just as the neoliberal state emerges in reaction to the perceived excesses of the Keynesian state, a "recessionary erotic economy" is emerging in response to the transgressive logic of the sexual revolution. ${ }^{38}$

The current era is one marked by sharp conflicts over sexuality. Sexuality, according to such theorists as Rubin and Weeks, has become more overtly politicized. In fact, a kind of panic logic prevails. ${ }^{39}$ The contemporary sexual panic follows a period of unprecedented sexual exploration and politicization. ${ }^{40}$ Central to the sexual revolution beginning in the 1960 s were the transgression of sexual authority, the emergence of conspicuous and proliferating sexualities that sought to violate sexual norms, and the politicization of sexual identities, including gays, lesbians, transsexuals and women, who sought enfranchisement of their desires. In the present context, the optimism of the sexual revolution has been undermined and identified by many actors as a cause of social decline. This is because the new sexual politics which were thrown open in the late twentieth century were profoundly unsettling, disrupting many taken-forgranted beliefs and "causing confusion in the mental universe of many people, especially those already

\footnotetext{
Doyle \& Lacombe, supra note 20 at 188.

Ibid.

L. Singer, Erotic Welfare (New York: Routledge, 1993) at 116.

Ibid.; Against Nature, supra note 2.

Singer, supra note 38 at 115-16.
} 
threatened by other changes." ${ }^{41}$ As Gamble notes, for example, sexual freedom has been condemned by many conservative critics for creating a "general questioning of authority and the undermining of the moral community represented by the traditional family." 42

Singer has emphasized how the discursive construct "epidemic," formed initially as a response to AIDS, has become the predominant contemporary discourse of the erotic. ${ }^{43}$ Treated as a retributive consequence of past transgressions, the discourse of sexual epidemic provides the rationale for heightened surveillance and repression of marginalized sexual communities. In this context, again, the figure of the child acquires immense symbolic significance. Seeking to chart what she describes as a moral panic around child pornography, Higonnet writes, ${ }^{44}$

Childhood has become sacrosanct. [We] place a high value on childhood not only because we care about how actual adults treat actual children, but also because we freight childhood so heavily with ideals. Once upon a time, the values of innocence, purity and nature could be variously located. Now we only seem able to find them in what we imagine to be the beleaguered bastion of childhood. If natural, pure innocence is equated with a complete absence of sexuality ... then sexual abuse of children violates the ultimate social taboo. From there it takes one step to blame child pornography.

It is this step that requires disentangling and it is this step that underlies the child pornography law and is cemented in the Supreme Court's decision in Sharpe.

The child as a symbol of innocence, asexuality and moral boundaries comes to represent sexual order. The visible sexuality of the child symbolizes, in turn, the violation of sexual order. Some social critics who have emphasized the hysteric character of contemporary attitudes to child pornography contend that this is an echo of an underlying moral panic around child sexual abuse. ${ }^{45}$ According to Doyle and Lacombe, recent reports of unprecedented increases in child sexual abuse and the proliferation of media stories focussed on extreme cases (the Maple Leaf Gardens case, for

${ }^{41}$ J. Weeks, Sexuality (London: Tavistock Publications, 1986) at 106.

42 A. Gamble, The Free Economy and the Strong State (Durham: Duke University Press, 1988) at 198

43 Singer, supra note 38.

${ }^{44}$ A. Higonnet, "Conclusions Based on Observation" (1996) 9 Yale J. Crit. 1 at 1 .

45 Doyle \& Lacombe, supra note 20. example) reflect and express changing definitions of child abuse and have resulted in highly exaggerated responses. ${ }^{46}$ Yet studies continue to show that the sexual coercion of children is a pervasive and highly underreported problem. ${ }^{47}$ Based upon a national population survey, the Badgley committee reported that fifty-three per cent of women and thirty-one per cent of men were sexually abused when they were children. ${ }^{48}$ In 1997, sixty-two per cent of sexual assaults reported to the police involved children and adolescents as victims (half of these were children under twelve). ${ }^{49}$

Feminist activism beginning in the 1970 s can claim much of the credit for breaking the silence around the sexual coercion of children. ${ }^{50}$ Feminist-inspired research challenged simplistic deviancy models and redefined child sexual abuse as a political and gendered problem. Among the underlying factors identified by feminist theorists and social researchers were: power imbalances between men and women and between adults and children that frame and enable sexual coercion; the predominant discourses that normalize sexual aggression and passivity as integral to institutionalized heterosexuality; and social structures sustaining privatized child-rearing that shroud the family in a veil of privacy. ${ }^{51}$ Empirical research lent support to this kind of politicized analysis that rooted child sexual abuse within prevailing definitions of masculinity, femininity and within the patriarchal nuclear family. For example, it is reported that in seventy-five per cent of cases, the accused is a family member or someone well known to the child. ${ }^{52} \mathrm{By}$ far the largest categories of offenders are fathers,

$46 \quad$ Ibid. at 191-98.

47 R.G. Rogers, Reaching For Solutions: Report of the Special Advisor to the Minister of National Health and Welfare on Child Sexual Abuse in Canada (Ottawa: National Clearinghouse on Family Violence, Health and Welfare Canada, 1990), online: Health Canada, National Clearinghouse on Family Violence <www.hc-sc.gc.ca/hppb/familyviolence /childsa.htm> (date accessed: 31 July 2001).

48 Badgley Report, supra note 5 at 193.

49 Canadian Centre for Justice Statistics, "Sex Offenders" (1999) 19:3 Juristat 1 at 11 .

50 M. Rivera, "Introduction" in M. Rivera, ed., Fragment by Fragment: Feminist Perspectives on Memory and Child Sexual Abuse (Charlottetown: Gynergy, 1999) 13 at 15.

51 Ibid.; A. Duffy, "The Feminist Challenge: Knowing and Ending the Violence" in N. Mandell, ed., Feminist Issues: Race, Class and Sexuality (Scarborough: Prentice Hall, 1995) 152 at 154-55, 165-68; Canadian Panel on Violence Against Women, Changing the Landscape: Ending Violence -- Achieving Equality -- Final Report (Ottawa: The Panel, 1993).

52 Badgley Report as cited in Government of Nova Scotia, Fact Sheet 5: Child Sexual Abuse (N.S .: Province of Nova Scotia, 2000), online: Province of Nova Scotia <http://www .gov.ns.ca/ coms/facts5.htm\#end4> (date accessed: 26 July 2001). 
stepfathers, uncles and older siblings. ${ }^{53}$ The gendered dimensions of child sexual abuse are revealed by consistent findings that men represent ninety-five per cent of perpetrators, while the majority of victims are girls. $^{54}$

This is not the place for an extensive examination of the complexities of child sexual abuse. What I want to highlight is how these complexities have been reduced to the most simplistic terms through the equation of child sexual abuse and child pornography; this is at the heart of the panic that I am seeking to identify. This insistent equation swirls within and frames the media and advocacy commentary on Sharpe. As feminist columnist Michele Landsberg reductively expresses it, "[c]hild pornography constitutes sexual abuse in itself." ${ }^{55}$ Similarly the child advocacy organizations Beyond Borders, CASE (Canadians Addressing Sexual Exploitation), EPCAT (End Child Pornography and Trafficking in Children for Sexual Purposes) and the International Bureau for Children's Rights contend that child pornography "is either the inducement of children to engage in unlawful sexual activity or the exploitative use of children in pornographic performances." 56 On the right, and expressing conservative anxieties about sexual pluralism, the Evangelical Fellowship of Canada argues that "[s]exual activity with children is one of the last taboos that is slowly breaking down. This [contemporary] belief that we make our own truth and are a law unto ourselves, would allow the consumption of child pornography and sex with children." ${ }^{57}$ In each of these expressions, there is a clear slippage from image to reality. Child pornography becomes constituted as the graphic public face of a practice that has been shrouded by secrecy and privacy. As image becomes reality, however, so too is reality contained within, distorted and simplified by representation.
The unbroken bridge between reality and representation is cemented through assertions of a virtual epidemic of child pornography. As Landsberg writes, for example, "the exposure of immense child pornography rings ... drives home the point that this is big, global business." ${ }^{, 58}$ But just how pervasive is the problem of child pornography? In a three year period from 1996-1999, the FBI's Innocent Images child pornography taskforce opened 2609 cases, with only twenty per cent of these generating indictments and just seventeen per cent resulting in convictions. ${ }^{59}$ According to an editorial in the Nation, "[t]his low number suggests that the problem is hardly of a scale to fit the [current] panic." ${ }^{60}$ Moreover, it is widely acknowledged that there is virtually no commercial market for child pornography. ${ }^{61}$ Child pornography circulates predominantly through the black market exchange of images facilitated by the Internet. ${ }^{62}$ But the privatized nature of exchange fuels other anxieties. Frequently conjured up is the image of the omnipresent and anonymous child pornographer invading the sanctity of the home through computer lines, tempting curious and vulnerable adults and luring unwary children onto pornographic sites. ${ }^{63}$ Yet again, however, the "epidemic" of Internet pornography tends towards exaggeration. As one indication, a 1995 investigation of 3.5 million America Online subscribers located only 125 child pornography offenders. As Higonnet asks, would we be as morally outraged if 125 might be guilty of another crime? ${ }^{64}$

The hysteria swirling around child pornography was clearly evident in reactions to the British Columbia Supreme Court and Court of Appeal decisions in Sharpe $^{65}$ that struck down the possession section of the Criminal Code as an invasion of freedom of expression and privacy. Doyle and Lacombe describe a panic spinning out of control in which the B.C. Law Courts were inundated with outraged calls. ${ }^{66}$ Both the trial judge and the accused/respondent were subjected to death threats. ${ }^{67}$ The Court of Appeal ruling was also harshly condemned by federal Members of Parliament, including one Reform member who asserted that it gave

53 Ibid.; R. Oldroyd, "Child Sexual Abuse: Statistics, Trends, and Case Outcomes" The Forum, online: Judicial Research and Statistics Association <www .jrsainfo.org/pubs/forum/archives/ Mar92.html> (date accessed: 26 July 2001).

54 Government of Nova Scotia, supra note 52; Badgley Report, supra note 5 at 215; Canadian Panel on Violence Against Women, supra note 51 at 11

55 M. Landsberg, "Porn law loopholes an affront to children's dignity" Sunday Star (4 February 2001) A4.

${ }^{56}$ R. v. Sharpe, [2001] S.C.J. No. 3 (Intervenor's Factum at 8) [hereinafter "Intervenor's Factum"].

57 Evangelical Fellowship of Canada, "Innocence Preserved: Protecting Children for Child Pornography" (Background Paper) September 2000 at 1, online: Evangelical Fellowship of Canada <http://www .efc-canada.com/na/docs/innoc.htm $>$ (date accessed: 31 January 2001).

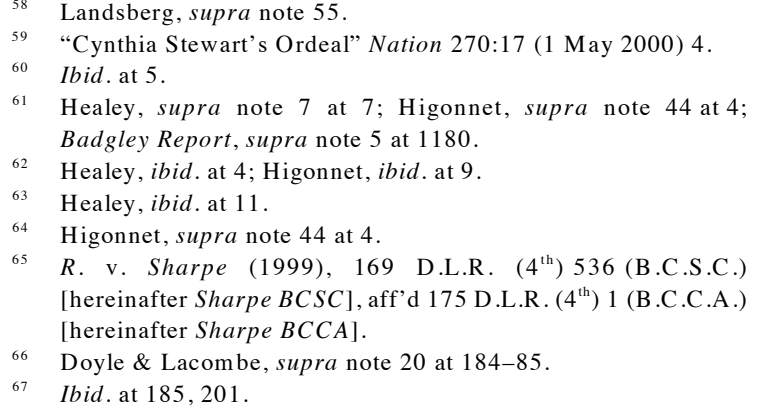


"pedophiles the right to abuse children." ${ }^{68}$ Here we can observe representation and reality flipping like two sides of the same coin, spinning into one.

At the heart of the contemporary panic around child pornography lies the symbolic figure of the "pedophile." It is through an analysis of this figure that we can observe the distortions that result from the equation of child pornography and child sexual abuse. John Robin Sharpe, of course, has become emblematic of this figure. How have we come to know him? He is first of all constructed as a pathological deviant, condemned not only for his activities (which consist mainly of possessing and producing sexually explicit representations of adolescents) but also for his identity. He has often been referred to as a pedophile, especially in the conservative media. ${ }^{69}$ Sharpe himself, although he is rarely permitted a voice in highly caricatured media representations, describes his sexual attractions as being directed at adolescent boys..$^{70}$ "Pedophilia," a psychiatric category, refers to an erotic attraction to prepubescent children. ${ }^{71}$ In the construction of Sharpe as a "pedophile" this pathologized category becomes elastic, extended beyond its definitional boundaries to include what are, under age of consent provisions, legal activities. $^{72}$

The insistent construction of Sharpe as a dangerous pedophile is striking when compared with other recent high-profile cases in which men have been accused of actually assaulting minors. Jack Ramsay, for example, a former Reform Party M.P., was convicted of the attempted rape of a fourteen-year-old native girl thirty years ago when he was an RCMP officer. While this conviction has been recently set aside and a new trial

68 Ibid. at 185 .

69 See e.g. "Child porn on to the Supreme Court" Alberta Report 26:29 (26 July 2000) 36 at 36.

70 Doyle \& Lacombe, supra note 20 at 195.

71 The Diagnostic and Statistical Manual of Mental Disorders lists the essential features of pedophilia as "recurrent, intense, sexual urges and sexually arousing fantasies, of at least six months duration, involving sexual activity with a prepubescent child" (American Psychiatric Association, Diagnostic and Statistical Manual of Mental Disorders, 3d ed. (Washington, DC: Author, 1987) at 284). The prepubescent child generally is thirteen years old or younger. The perpetrator is sixteen years old or older, at least five years older than the victim, and has an enduring and exclusive sexual interest in children. The majority of pedophiles and child molesters are men, according to the DSM-IV. Most often pedophiles are relatives, friends, or neighbours of the child victims (American Psychiatric Association, Diagnostic and Statistical Manual of Mental Disorders, 4th ed. (Washington, DC: Author, 1994) at 528) [hereinafter DSM-IV].

72 Doyle \& Lacombe, supra note 20 at 195-96; S. Bell, "On ne peut voir l'image [The image cannot be seen]" in Cossman et al., supra note 12,199 at 208. ordered, Ramsay has admitted to sexual touching. ${ }^{73}$ This incident was non-consensual and clearly an abuse of power. There is, however, a qualitative difference in the media treatment of Ramsay. Reports of the accusations have adopted an objective ${ }^{74}$ and even forgiving posture - this was a forgivable error in judgment. Jack Ramsay has not been represented as a "pedophile." Sharpe, by contrast, who has not yet even been convicted of possessing child pornography and has never been accused of sexual assault, has become, in Doyle and Lacombe's words, "not just a child pornographer, but a pedophile and a freak - something to be policed." ${ }^{75}$ There is an odd contradiction evident in these differing responses to child pornography and to allegations of actual child sexual abuse. We are encouraged to castigate images, pathologize their possessors and at the same time, to deny practices; once again, image and reality become inverted.

The constructed image of the child pornographer not only works to shift our attention to representation, it also functions to deny the systemic nature and characteristics of child sexual abuse. As I have argued earlier, child sexual abuse is overwhelmingly a heterosexual crime. This is erased in the dominant construction of the pedophilic child pornographer as homosexual. Representations of Sharpe have focussed obsessively on his homosexuality. ${ }^{76}$ In this manner, the pedophile and the homosexual are twinned, presented as if inevitably linked. Cossman and Bell contend that this fusion has precipitated a prosecutorial focus on homosexual representations; the child pornography law, as with other laws crafted to regulate sexual expression, becomes a means of policing and stigmatizing sexual minorities. ${ }^{77}$ Not only this, however, but linkage between child pornography and male homosexuality also works to relegitimize deviancy models of child sexual abuse. Its "troubling" existence in the "normal" heterosexual family is obscured, as ultimate responsibility is projected onto the "pathological" outsider.
73 See R. v. Ramsay, [2001] S.J. No. 17 at para. 10 (Sask. C.A.).

74 See $e . g$. L. Coolican, "Ramsay retrial date set on attempted-rape charge" The Edmonton Journal (13 March 2001) B5.

75 Doyle \& Lacombe, supra note 20 at 185.

76 Ibid. For example, the Alberta Report refers to Sharpe's stash of "homosexual erotica," referring to Sharpe as both a "Vancouver homosexual" and a "pedophile." This representation works to fuse the categories homosexual and pedophile. Alberta Report, supra note 69; "If it feels good, stop" Alberta Report 26:33 (30 August 2000) 28 at 28.

77 Cossman \& Bell, supra note 12 at 41 . 
Child pornography is relentlessly portrayed as a threat from the outside. Arguments about the epidemic proportions of child pornography are deployed in order to justify the need to draw boundaries around the threatened home. As one legal commentator on the constitutionality of section 163.1 of the Criminal Code hyperbolically insists, for example, "the Internet is fast becoming the most significant factor in the sexual abuse of children." ${ }^{78}$ In this exaggerated and misleading narrative, the "child pornographer/child sexual abuser/pedophile" moves invisible among us, but is always outside trying to sneak in. A similar narrative emerges in a poster campaign launched in Sharpe's Vancouver neighbourhood, in which he is portrayed as a threat to the family and to the community. He comes to symbolize the child pornographer invading the safety of our neighbourhoods by stealth. As the poster warns, "watch for him ... because you have to know he is watching you.,"79

In many ways, as my discussion suggests, the contemporary panic around child pornography constitutes a backlash against feminist inspired insight that child sexual abuse is social, structural and systemic, with the privatized family constituting one of its main forums. We are encouraged to focus on the evil outsider and against this "dangerous" outside, the family reconstituted as a safe haven. Through these interchanges between public and private, children's sexuality is located within the private, a private sphere where above all else they need protection from sexual explicit images, and where they are positioned as innocent and powerless victims.

I have been describing a political and cultural context in which our legitimate concerns about the well-being of children have been persistently narrowed. Through the law and order state and its preferred instrument of criminalization, our anxieties about the welfare of children become directed onto the problem of child sexual abuse, defined principally as a criminal justice issue. Through panicked reactions to child pornography, the complex social, systemic and gendered dimensions of child sexual abuse virtually disappear, replaced with the repetitive slippage from reality to representation. This equation of child pornography and child sexual abuse is reiterated, cemented and legitimized in the recent Supreme Court decision in Sharpe.

78 S. Anand, "A Case for Upholding the Child Pornography Law" (1999) 25 C.R. $\left(5^{\text {th }}\right) 313$.

79 Doyle \& Lacombe, supra note 20 at $185-86$.

\section{THE SUPREME COURT DECISION IN SHARPE}

With the force of the two lower court decisions in Sharpe,${ }^{80}$ the edifice upon which the child pornography law was erected was perilously shaken. Relying upon a series of interlinked arguments, the trial judge and two of the three Court of Appeal Justices ruled that section 163.1(4) of the Criminal Code (the possession section) constituted an unjustifiable intrusion on freedom of expression. ${ }^{81}$ First, the uniqueness of a criminal possession offense was highlighted by the B.C. Court of Appeal. ${ }^{82}$ It is crucial to remember that it is not a criminal offence to possess other harmful expressive materials, including texts that advocate genocide. ${ }^{83}$ Drawing on classic civil libertarian reasoning, Southin J.A. argued that because a possession offence comes precipitously close to criminalizing thought, "the hallmark of tyranny," 84 it can never constitute a justifiable limitation on freedom of expression. Second, and in the alternative, Southin J.A. emphasized that because privacy and expression rights are implicated, for a possession offense to constitute a reasonable limitation on constitutional freedoms the most compelling evidence of necessity is required.$^{85}$ The test established by the Supreme Court in Butler, requiring a "reasoned apprehension of harm" 86 for limiting expression, is thus insufficient. Echoing the trial decision, Southin J.A. contended that there is little conclusive evidence linking the possession of child pornography to increases in child sexual abuse. While some studies have found that "highly erotic materials" 87 incite offences, others suggest that such materials reduce the incidence of abuse by relieving sexual tensions. Similarly, while pornography involving children may reinforce "cognitive distortions" belief that sex with children is normal), there is no evidence linking this with an increase in harm to

\footnotetext{
Supra note 65.

Sharpe BCCA, supra note 65.

Ibid. at paras. 88-95 per Southin J.A.

"Intervenor's Factum," supra note 56 at para. 18; possessing materials advocating genocide is not a criminal offence (Criminal Code, R.S.C. 1985, c. C-46, as added by S.C., c. 19 (3d Supp.), s. 1, s. 150.1; Criminal Code, ibid., s. 318).

${ }^{84}$ Sharpe BCCA, supra note 65 at para. 95 per Southin J.A.

85 Ibid. at para. 124.

6 Butler, supra note 11 at $483-84$

87 The trial judge's findings of fact in Sharpe BCSC, supra note 65 at para. 19. These findings were based upon literature reviewed by expert Dr. P.I. Collins, forensic psychiatrist. These findings include both the harmful and the beneficial cathartic effects of child pornography. For a discussion, see J. Ross, " $R$. v. Sharpe and Private Possession of Child Pornography” (2000) 11 Constitutional Forum 50 at 52.

${ }^{88}$ Sharpe BCSC, supra note 65 at para. 13
} 
children. ${ }^{89}$ Finally, Rowles J.A. of the B.C. Court of Appeal emphasized that an overbroad definition of child pornography, in combination with a possession offense, led to the criminalization of many materials that posed little risk of harm to children, including: selfcreated and privately held works of the imagination; sexual self-representations created by adolescents; and private written materials that advocate sex with those under eighteen. ${ }^{90}$

In striking down section 163.1(4), the two lower court decisions undermined the easy equation of child pornography and sexual abuse and the myopic focus on representation that this induces, delegitimizing a law that is, as I have argued, heavily weighted with symbolism. The intensity of political reactions to these decisions demonstrates the extent of symbolic investment in the child pornography law. There was an unprecedented level of legislative support for introducing the notwithstanding clause should the law be struck down on appeal to the Supreme Court, with the Federal Justice Minister suggesting that the government would keep this option open. ${ }^{91}$

It is critical to set the recent Supreme Court decision in Sharpe against this broad backdrop. Some media commentators, child advocacy organizations and the right-wing Alliance Party reacted with outrage to the Sharpe decision, arguing that it created "a loophole for pedophiles." 92 Far from weakening the criminal regulation of child pornography, I want to suggest that the main impact of the Supreme Court decision has been to strengthen the law by re-establishing its legitimacy and the web of connections between representation and child sexual abuse upon which it rests.

With resounding unanimity, the Supreme Court upheld the possession section as a reasonable limit on expression in the context of social problem hyperbolically described as nothing less than "an evil." 93 The $6 / 3$ division in the judgment arose on the appropriate interpretation of the definition of child pornography and whether or not the possession sections caught relatively harmless categories of sexual representation. The majority judgment, written by McLachlin C.J.C., sought to clarify and darken the line

$89 \quad$ Ibid. As Southin J.A. comments, Collins' testimony (supra note 86), which emphasized the attitudinal harms of child pornography, was opinion rather than objective fact (Sharpe $B C C A$, supra note 65 at paras. 65-66 per Southin J.A.).

90 Sharpe BCCA, supra note 65 at paras. 177-207 per Rowles J.A.

91 Landsberg, supra note 55; J. Armstrong, "Kiddie-porn law headed to top court" The Globe and Mail (1 July 1999) A1.

92 Landsberg, supra note 55; "Supreme Court backs bulk of child porn law" CBC News (26 January 2001) 22:43:09.

93 Sharpe, supra note 1 at paras. 28, 93 per McLachlin C.J.C. around "harmful" and thus justifiably prohibited representations, reading in two narrow exceptions to the prohibitions on possession in order to remedy the law's overbreadth. The dissent, penned by L'Heureux-Dubé J., departed from the majority both in casting a much wider net over the range of representations falling within the meaning of child pornography and in emphatically denying its overbreath. While there are undeniable differences in tone in these two opinions, they sing in harmony on one fundamental point that is repeated endlessly throughout the decision as a whole - prohibiting the possession of child pornography reduces child sexual abuse.

This refrain is articulated most clearly in the dissenting judgment in which child pornography comes to colonize virtually all sexual representations of adolescents and children and is itself defined as an activity - that is, child sexual abuse. The tenuous relationship between the simple possession of child pornography and the activity of sexual coercion is transformed into certainty in the narrative woven by L'Heureux-Dubé J. While acknowledging a "dearth"94 of scientific evidence, she nevertheless declares that "a correlation between greater access to child pornography and child sexual abuse does exist." ${ }^{95}$ L'Heureux-Dubé $\mathrm{J}$. finds section 163.1(4) a justifiable limit on freedom of expression primarily because there is always a danger that materials will find their way into the hands of "paedophiles." 96 The virtually uncontainable danger of sexual representations of all those under eighteen, even privately held works of the imagination, even the diary entries of adolescents, are located here in the ever-present possibility of their "dissemination." "pedophile," the deviant outsider, assumes an insistent presence here. He is the obsessive collector of any image, even crude drawings, suggesting underage sexuality ${ }^{98}$ he cleverly deploys pornography to "groom" children" and yet is himself oddly childlike, acting out his "deviant" desires prompted by the cue of representation. ${ }^{100}$

\footnotetext{
Ibid. at para. 201 per L'Heureux-Dubé J.

Ibid. at para. 202.

96 She even extends this hyper-elastic category to include teenagers producing self-images, arguing that "there is no valid reason to presume that teenage authors of sexually explicit videos cannot themselves be pedophiles" (ibid. at para. 212). According to the DSM-IV, this falls outside the pathological category pedophile - "The perpetrator is sixteen years old or older, at least five years older than the victim, and has an enduring and exclusive sexual interest in children." (DSM-IV, supra note 71).

97 Ibid. at para. 164 per L'Heureux-Dubé J.

98 Ibid. at para. 219.

99 Ibid. at paras. 205-10.

100 Ibid. at para. 201.
} 
The tone of McLachlin C.J.C.'s opinion is, by contrast, measured; the thrust, some would assert, is "liberalizing." But the liberalization she offers is restricted and must be seen within the opinion as a whole. Her opinion opens with an abstracted analysis of the constitutional values at stake in the case. ${ }^{101}$ McLachlin C.J.C. pronounces on the constitutional issues that are implicated by section 163.1(4) before laying out a definition of "child pornography." In this way, child pornography becomes an indefinite term into which meaning may be poured indiscriminately. The judgment thus begins with the assertion that child pornography, both loaded with meaning and undefined, lies far from the values of freedom of expression. In ten short paragraphs, she asserts that it (all sexual representations of those under eighteen? or only some?) is "prurient,"102 "base,"103 "offensive,"104 "does not contribute to the search for truth or to Canadian social and political values," and is linked only with the value of self-fulfillment. ${ }^{105}$ Drawing on common sense meanings allows McLachlin C.J.C. to construct this as yet undefined category of representations in thoroughly negative terms. By contrast, she articulates the countervailing interests as normatively good and imperative. Society has an interest, she insists, in "protecting children from the evils associated with the possession of child pornography." 106 In emphatic language, she claims that child pornography (again, all sexual representations of those under eighteen? even imaginative representations?) "involves the exploitation of children." 107 The equation of representation and reality is thus established at the outset of this "liberalizing" opinion.

The liberalizing appearance of the majority judgment lies principally in its efforts to clarify and rein in the definition of "child pornography." McLachlin C.J.C. so desperately wants to render the meaning of "child pornography" constitutional that she at times interprets section 163.1 in ways that depart from its clearly expansive wording. For example, while included in the statutory definition are visual representations of those "depicted as being under eighteen" McLachlin C.J.C. insists that this be given an objective meaning. The proper interpretation, she argues, lies in the "sense that would be conveyed to a reasonable observer." ${ }^{108}$ In other words, to be child pornography the image must seem to be believably of a child. The danger of

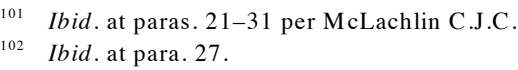

101 Ibid. at paras. 21-31 per McLachlin C.J.C.

$$
\begin{array}{ll}
103 & \mathrm{Ibid} . \text { at para. } 24 . \\
104 & \mathrm{Ibid} . \text { at para. } 21 . \\
105 & \mathrm{Ibid} . \text { at para. } 24 . \\
106 & \mathrm{Ibid} . \text { at para. } 28 . \\
107 & \mathrm{Ibid} . \\
108 & \mathrm{Ibid} . \text { at para. } 43 .
\end{array}
$$$$
108 \text { Ibid. at para. } 43 .
$$

depicting someone pretending to be under eighteen, she contends, lies in the potential for this representation to be used "for the purposes of seduction"; ${ }^{109}$ the linkage between image and action seems to appear most frequently in this opinion when it is probing the outer edges of the expansive statutory definition. Linking the danger of depiction to the potential of seduction serves to legitimize the criminalization of representations of adults pretending to be children. Yet making the test for depiction the believability of the pretense, McLachlin C.J.C. reins in one clear source of the law's overbreadth.

In order to fall within the criminalized category of child pornography, the majority judgment emphasizes that the visual representations must be explicit, involve nudity and have a clear sexual purpose defined as being "intended to cause sexual stimulation." "110 A photo of a child in the bath would not, in most instances, fall within the proper interpretation of child pornography and in this way, the elasticity of the statutory definition is again restricted. But McLachlin C.J.C. leaves open the potential for the same image to be criminalized in certain contexts. Departing from the literalist approach inherent in the legislation, the meaning of visual sexual representations becomes linked with context in the judgment. Should the same photo of a child in the bath be found among other clearly sexual images, McLachlin C.J.C. suggests, its meaning could change. ${ }^{111}$ Peaking through this contextual gesture is the suggestion that should this photo be found on a "pedophile's" computer, it becomes child pornography - its danger becomes contingent upon the identity of its possessor.

Perhaps the most significant aspect of the judgment lies in its explicit redefinition of the provision on written materials. McLachlin C.J.C. dramatically narrows the thrust of the provision; prohibited written materials must explicitly "advocate" or "counsel" in the sense of actively promoting, "the commission of sexual offences with children." "112 The majority judgment erects a distinction between materials that explore sex with children (materials such as Plato's Symposium and anthropological studies) and those that send "the message that sex with children can and should be pursued." ${ }^{113}$ This distinction is one that could be seen as consistent with the statutory wording. Yet in linking "counselling" with criminal sexual activity, McLachlin C.J.C. moves far from the statutory definition of written child pornography. Even though section 163.1(1)(b)

\footnotetext{
Ibid.

110 Ibid. at paras. 44-53. The quotation is at para. 50.

111 Ibid. at para. 51.

112 Ibid. at para. 55

113 Ibid. at para. 56.
} 
refers to "activity with a person under the age of eighteen," McLachlin C.J.C. contends that it was not intended to criminalize written materials that include sexual representations of fourteen-to-seventeen-yearsolds when the sexual activity is consensual and does not involve payment or the abuse of trust. ${ }^{114}$ The problems that arise from the criminalizing depictions of adolescent sexuality are partially addressed through this blatant judicial redefinition.

There is an evident difference in the treatment of written and visual materials within McLachlin C.J.C.'s discussion of the proper interpretation of child pornography. Pictures that show even nudity are vulnerable to criminalization while words that describe sexual activity can, very often, escape. Visual materials that depict fourteen-to-seventeen-year-olds are cast into the dark container of child pornography while written depictions of adolescent sexuality, for the most part, remain outside. Here the visual is presented as inherently more dangerous than text: pictures speak louder than words. Why is this? First, because according to McLachlin C.J.C., the meaning of the written is more open to interpretation; therefore, as the Court held in Little Sisters, ${ }^{115}$ "it may be difficult to make the case of obscenity against written texts."116 Second, and implicit in this judgment, is the assumption that the visual is more open to literal interpretation. Pictorial images often come to visually mark the transgression of the boundary between adult and child and symbolically represent child sexual abuse. In this construction, and in the visual/text distinction upon which it rests, we can see how the precision that McLachlin C.J.C. so desperately attempts to write onto the definition of child pornography remains illusive; representations of adolescents are cast as both necessarily within and outside the category of child pornography.

The liberalizing guise of this opinion, as well as its residual and yet firmly denied instabilities are also apparent in the discussion of statutory defenses. McLachlin C.J.C. insists that the defenses of "artistic merit," "educational, scientific and medical purpose" and "public good" be given a broad meaning. ${ }^{117}$ As for artistic merit, this includes anything that "may reasonably be viewed as art."118 A valid claim must include more than the intent of the producer, and the standard set for each of these defenses is the standpoint

114 Ibid. at para. 58.

115 Little Sisters Book and Art Emporium v. Canada (Minister of Justice), [2000] 2 S.C.R. 1120.

116 Sharpe, supra note 1 at para. 103 per McLachlin C.J.C.

117 Ibid. at paras. 61-71.

118 Ibid. at para. 63. of the reasonable observer. ${ }^{119}$ While McLachlin C.J.C. lists a number of factors that could be used in the determination of "artistic merit," she defers the refinement of these factors to the development of case law. ${ }^{120}$ The art/porn distinction is at once asserted and yet remains highly unstable. Grounding this discussion is an insistence that sexual representations of children and adolescents must be connected with some other purpose to render them valuable. Sexual representations that are not linked to some higher purpose remain "base" 121 and "prurient." "22 But the line between good and bad, valuable and dangerous, remains permeable despite McLachlin C.J.C.'s assertions to the contrary.

The underlying purpose of these efforts to darken the line around prohibited representations is made explicit in the majority's analysis of whether the limits on freedom of expression imposed by the possession section can be "demonstrably justified in a free and democratic society" - the Charter section 1 analysis. ${ }^{123}$ As McLachlin C.J.C. insists, "Many of the ... hypothetical examples relied on in the courts below as suggesting overbreadth either disappear entirely on a proper construction of the statutory definition of child pornography, or are narrowed to the extent that material is caught only where it is related to harm to children." 124 Creating the appearance of clarity, of a dark line containing harmful representations, allows McLachlin C.J.C. to move the possession section close to a constitutional standard. As I have suggested, however, the appearance of a dark line is deceptive. It rests on a chain of unstable distinctions - adolescent/child; counsel/describe; word/image; art/porn. Nonetheless, the assertion of precision serves a rhetorical purpose in the opinion, permitting McLachlin C.J.C. to pronounce unequivocally on the dangers that flow from the

\footnotetext{
Ibid. at paras. $64,68,70$.

Ibid. at para. 64

121 Ibid. at para. 24.

122 Ibid. at para. 27

123 Section 1 of the Charter of Rights and Freedoms reads "The Canadian Charter of Rights and Freedoms guarantees the rights and freedoms set out in it subject only to such reasonable limits prescribed by law as can be demonstrably justified in a free and democratic society" (Canadian Charter of Rights and Freedoms, Part 1 of the Constitution Act, 1982, being Schedule B to the Canada Act 1982 (U.K.), 1982, c. 11, s. 1). As McLachlin C.J.C. explains, "[t]o justify the intrusion on freedom of expression, the government must demonstrate ... that the law meets the test set out in R. v. Oakes, [1986] 1 S.C.R. 103 and refined in Dagenais v. Canadian Broadcasting Corp., [1994] 3 S.C.R. 835 and Thompson Newspapers Co.v. Canada (Attorney General), [1998] 1 S.C.R. 877. The goal must be pressing and substantial, and the law enacted to achieve the goal must be proportionate in the sense of furthering the goal, being carefully tailored to avoid excessive impairment of the right, and productive of benefits that outweigh the detriment to freedom of expression" (Sharpe, supra note 1 at para. 78).

124 Sharpe, supra note 1 at para. 98 per McLachlin C.J.C.
} 
possession of child pornography - the contents of the dark container.

In its section 1 analysis we can see most clearly how the majority's narrative becomes caught up in the same discursive web woven by the dissent. At the heart of this web lies the equation of child pornography and sexual abuse. Prohibiting possession, argues McLachlin C.J.C., is rationally connected with the pressing goal of reducing the sexual exploitation of children. ${ }^{125}$ In assessing rational connection, McLachlin C.J.C.departs significantly from the two lower court decisions in this case, re-establishing "reasoned apprehension of harm" as the standard. ${ }^{126}$ Moving from concrete evidence to "apprehended harm" permits the assertion that even without proof, we can predict that the possession of child pornography leads to child sexual abuse.

McLachlin C.J.C. frames the clear dangers of possession in the following ways:

“exposure ... may reduce paedophiles' defenses and inhibitions against sexual abuse of children;",127

"possession ... fuels fantasies, making paedophiles more likely to offend;" 128

"criminalizing $\ldots$ possession $\ldots$ aids in prosecuting ... distribution and use;",129

"[s]exually explicit pornography involving children poses a danger ... because of its use by $p[a]$ edophiles in the seduction process;"

"[c]riminalizing possession may reduce the market ... and the abuse of children it often involves." 131

Of these factors, only the final harm is conclusive and only in relation to a narrow category of representations - children are harmed in making visual pornography. The fourth factor, the use of pornography in seduction, is presented as being "clear and uncontradicted."132 It is, nevertheless, important to recognize there have been no studies that would point to its significance as a causal and pervasive factor in child sexual abuse (even though such studies could be

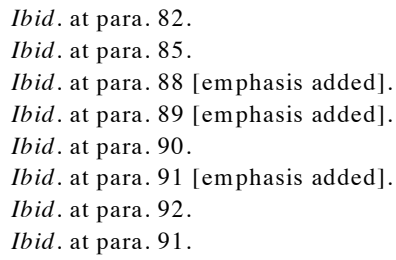

done using trial transcripts to see how frequently grooming through pornography actually occurs in reported cases). The first two factors that child pornography weakens pedophiles' "inhibitions against sexual abuse of children" and that child pornography "fuels" pedophiles' "fantasies" are based on research that is contradicted by studies demonstrating how the use of pornography may actually inhibit sexual abuse by relieving tensions. ${ }^{133}$ The tenuous nature of the linkages between representation and reality made evident in the lower court decision become transformed into certainty here. Based upon "social scientific evidence," "buttressed by experience and common sense," McLachlin C.J.C. strongly concludes that "[p]ossession of child pornography increases the risk of child abuse."134

As in the dissent, the dangers of child pornography are projected onto the figure of the pedophile; he is repeatedly invoked in the majority's section 1 analysis. $\mathrm{He}$ is presented as the bridge between representation and reality, especially when the dangers of possession seem most difficult to establish. Echoing and at the same time legitimizing the moral panic on which the child pornography legislation depends, the Sharpe decision creates a condensation. Its readers are moved from the broad concerns about "preventing harm to children" to the problem of "child sexual abuse" to "child pornography" and then back again, repeatedly assured along the way that banning possession will enhance child welfare. In the seductive loop of this judgment, there is much that is eclipsed. The seriousness and complexity of child sexual abuse, the very problem that Parliament claimed to be addressing through enacting section 163.1, is never explored, except through the flat assertion that child pornography increases child sexual abuse. In this way, image and action are not only fused, image comes to replace reality. With the insistent presence of the 'pedophilic child pornographer' invoked thirty-two times in the judgment as a whole, ${ }^{135}$ our concerns about sexual abuse are projected outwards, away from the home and family, away from the everyday.

Oddly, if child sexual abuse is represented opaquely in the judgment, so too is child pornography. McLachlin C.J.C. is most concerned to probe the edges of the category, to create the appearance of a clear

133 As the trial judge summarized the conflicting findings of the existing social science research in her findings of fact: " $[\mathrm{h}]$ ighly erotic" pornography incites some pedophiles to commit offences; "[h]ighly erotic" pornography helps some pedophiles to relieve sexual tension; " $[\mathrm{m}]$ ildly erotic" pornography appears to inhibit aggression (Sharpe BCSC, supra note 65 at para. 19).

134 Sharpe, supra note 1 at para. 94 per McLachlin C.J.C.

135 Sharpe, supra note 1. A word count of the decision revealed that the word "pedophile" appeared 32 times. 
distinction between the dark container and that which lies outside. She finds that the definition created by the legislation broadly targets undeniably harmful representations. To the extent that it catches too much, however, it is only with respect to two narrow categories of representations: "[s]elf- created expressive material ... created by the accused alone ... exclusively for his or her own personal use"; and "[p]rivate recordings of lawful sexual activity ... created by or depicting the accused, provided it does not depict unlawful sexual activity and is held by the accused exclusively for private use."136 Such materials, including private writings and "adolescents recording themselves," McLachlin C.J.C. argues, pose little risk of harm to children ${ }^{137}$ and to criminalize their possession "deeply implicates section 2(b) freedoms" bordering on thought control. ${ }^{138}$ She therefore finds that because the possession section catches such peripheral materials, it fails to meet the proportionality test. For this reason, she chooses to read in two exceptions to section 163.1(4) to exclude these narrow categories of representations.

It is largely on the basis of this remedy that some media commentators and child advocacy organizations have condemned the decision. In this view, the main impact of Sharpe is the creation of "loopholes" in the child pornography law. But just how wide are these "loopholes" and what is their rhetorical purpose in the decision as a whole? It is clear that self-created privately held works of the imagination and private sexual self-representations of adolescents are caught by section 163.1(4). The majority opinion, however, emphasizes that the central danger of child pornography (aside from sexual exploitation in production) lies in its dissemination (to pedophiles). Materials that are not communicated fall outside this logic; they also constituted the bulk of the "hypotheticals" relied on by the respondent and civil libertarian intervenors. Creating these narrow exceptions allows McLachlin C.J.C. to resolve the contradiction between, on the one hand, allowing adolescents to legally engage in sexual activity, and on the other, disallowing any form of representation of this activity. And like her acrobatic efforts to create precision in the definition of child pornography, the creation of these exceptions enables her to pronounce unequivocally on the harms of the dark container.

As June Ross has argued, the B.C. Court of Appeal's focus on "incidental hypotheticals" and overbreadth diverted attention from the "hard" cases, from the kinds of material possessed by Sharpe, from

\footnotetext{
Ibid. at para. 115

37 Ibid. at para. 105

138 Ibid. at para. 108
}

the presumed contents of the "dark container." ${ }^{139}$ Ross contends that "overbreadth arguments are employed as a guise to cover uneasiness about the law's application even to its 'targets' and can be used as a constitutional justification for weakening a law that has a moral imperative." ${ }^{140}$ As I have suggested, however, when the interior of the dark container of child pornography remains opaque, we, as readers, are drawn into the seductive loop of assumed linkages between the welfare of children, child sexual abuse and child pornography that the decision serves to re-establish. What would happen if we allowed the child pornographer to speak? What would happen if we were forced to interrogate the proposition that child pornography causes sexual abuse with reference to the kind of images and texts possessed and created by Sharpe? This is the work that is done in Bell's analysis in this issue. This is precisely the kind of hard work that the decision in Sharpe avoids. Bell's analysis of the "hard cases" questions a simplified equation of representation and harm and asks us to consider instead the social value of specific sexually explicit texts and images. Through this analysis, the distinctions upon which McLachlin C.J.C.'s interpretation rests - adolescent/child; counsel/ describe; word/image; art/porn — are revealed as highly precarious.

\section{CONCLUSION}

The main impact of the Sharpe decision, as I have insisted, has been to re-legitimize the equation between representation and reality that lies at the heart of the current moral panic around child pornography. Federal Justice Minister Ann McLellan predictably seized upon Sharpe as a victory: “Today's Supreme Court decision is a victory for our children. The Government's priority throughout this case has been, and will continue to be, the safety of our children." ${ }^{141}$ Just three weeks after the release of the decision, deploying the legitimacy bestowed by the Supreme Court in Sharpe, McLellan announced new legislation targeting the Internet transmission of child pornography. This legislation, yet to be introduced, would add another layer of criminalization to sexual representations of children, with penalties of up to ten years for distribution on the Internet, added to existing penalties for possession and distribution for child pornography. ${ }^{142}$

\footnotetext{
Ross, supra note 86 at 50.

140 Ibid. at 55-56.

${ }^{141}$ Canada, Department of Justice, "MINISTER OF JUSTICE ISSUES STATEMENT ON R.v. SHARPE” (27 January 2001), online: Department of Justice Canada <http://canada.justice. gc.ca/en/ news/nr/2001/doc_25860.html> (last modified: 27 July 2001).

142 T. Barrett, "McLellan to toughen laws against Internet predators" The Edmonton Journal (14 March 2001) A1, A14.
} 
In all this focused legislative and judicial attention on the evils of child pornography, we are pulled into a reassuring web of connections, from the "safety of our children" to the prevention of "sexual abuse" to the eradication of the "pornography" that enables this. But this reassurance comes at a cost, as I have suggested in this article. Defining child pornography as an ultimate evil induces a tunnel vision in which real threats to the welfare of children, from poverty and disintegrating social programmes to the complexities and pervasiveness of child sexual abuse, are obscured. In this way, the current hysteria around sexualized images of children can be seen a backlash against social structural analysis of disadvantage and disempowerment - a backlash that is entirely consistent with the myopic vision of the law and order state.

There are justifications for criminalizing possession when child pornography is carefully defined as images that involve the sexual abuse of children in their production. Achieving precision in criminal prohibitions on child pornography beyond the illusion created in McLachlin C.J.C.'s reasoning also necessarily involves erecting a clear line between adolescent and child. It is incongruous to recognize that adolescents can consent to sexual activity and then to criminalize any non-private expression of adolescent sexuality. The Sharpe decision tells us that young people's sexual expression is permitted only so long as it is never communicated - young people cannot use sexual imagery to create fantasies, to challenge oppressive sexual norms, to work out sexual boundaries or enhance their sexual autonomy. They cannot, in short, be the authors of their own sexualities because of the ever-present danger that this material might fall into the hands of "pedophiles." It may well be that allowing adolescents agency within the realm of sexual representation could help to combat sexual coercion and domination. The recognition that sexual texts and images can have value in themselves will, however, necessitate escaping from the unremitting sex negativity that frames Canadian judicial thinking on pornography.

\section{Lise Gotell}

Women's Studies Program, University of Alberta. I wish to thank Tsvi Kahana for editorial advice, Karen Gawne for her work on copy-editting and Leah Lis for assistance with references. 